\title{
Analisis Anomali Bouguer Data Gaya Berat Studi Kasus di Kota Lama Semarang
}

\author{
Bouguer Anomaly Analysis of Gravity Data \\ Case Study in Kota Lama Semarang
}

\author{
Yeni Rima Liana*1, Tri Maria Magdalena W2 ${ }^{2}$, Wihdatus Syarifah ${ }^{3}$, Supriyadi Supriyadi' ${ }^{4}$, Khumaedi \\ Khumaedi $^{5}$ \\ 1,2,3,4,5)ProgramStudi Pendidikan Fisika, Pascasarjana, Universitas Negeri Semarang \\ Jalan kelud III, Kota Semarang 50237 \\ email: ${ }^{* 1}$ yrimaliana21@gmail.com, ${ }^{2}$ trimariamagdalenawea@gmail.com, ${ }^{3}$ wihda_assyarifah@yahoo.com, \\ ${ }^{4}$ supriyadi@mail.unnes.ac.id, ${ }^{5}$ medisas@mail.unnes.ac.id
}

DOI;

$10.30595 /$ jrst.v4i2.6301

HistoriArtikel:

Diajukan:

$02 / 01 / 2020$

Direvisi:

$16 / 06 / 2020$

Diterima:

$22 / 09 / 2020$

\section{ABSTRAK}

Kota Lama Semarang merupakan salah satu obyek wisata sejarah yang berada di kota Semarang dan pada tahun 2016 masuk sebagai salah satu nominasi World Heritage Site. Penelitian ini bertujuan untuk melakukan analisis anomali Bouguer data gaya berat studi kasus di Kawasan Kota Lama Semarang untuk membantu mengidentifikasi struktur bawah permukaan tanah di Kawasan tersebut yang setiap tahunnya selalu terjadi banjir rob, genangan air dan penurunan permukaan tanah. Pengolahan data anomaly Bouger menggunakan software Oasis Montaj 6.4.2. Penelitian ini tersebar 24 titik di Kawasan Kota Lama selama 2 hari. Tahap awal dilakukan koreksi pasangsurut (TC) dan koreksi apungan (DC). Tahap berikutnya dilakukan koreksi lanjut yang terdiri dari koreksi udara bebas (FAC) dan koreksi Bouguer (BC) hingga didapat kontur anomaly udara bebas (FAA) dan kontur anomali Bouguer (BA). Nilai BA di Kawasan Kota Lama Semarang dengan interval 10,58 mGal s.d 11,65 mGal dengan koreksi FAC mempunyai rentang 1,48 mGal s.d 3,09 mGal, anomali FAA mempunyai rentang 11,1 mGal s.d 12,7 mGal serta koreksi gobs mempunyai rentang 978118,88 mGal s.d 978118,50 mGal. Kawasan dengan anomali Bouguer tinggi memiliki struktur batuan dengan densitas yang tinggi dibandingkan dengan Kawasan lainnya. Nilai anomali Bouguer semakin keutara semakin rendah, dan semakin keselatan semakin tinggi.

Kata Kunci: anomali Bouguer, gaya berat, Kota Lama Semarang

\begin{abstract}
Kota Lama Semarang is one of the historical attractions in the city of Semarang and in 2016 entered as one of the World Heritage Site nominations. This study aims to analyze Bouguer anomalies in gravity of case study data in Kota Lama Semarang to help identify subsurface structures in the area, which every year there is always tidal floods, standing water and subsidence. Bouger anomaly data processing used Oasis Montaj software 6.4.2. This research is famous for 24 points in the Kota Lama area for 2 days. The first step is tidal correction (TC) and floating correction (DC). The next step was to make further corrections consisting of free air correction (FAC) and Bouguer correction (BC) to obtain free air anomaly contour (FAA) and Bouguer anomaly contour (BA). BA value in Kota Lama Semarang with intervals of $10.58 \mathrm{mGal}$ to $11.65 \mathrm{mGal}$ with FAC correction has a range of $1.48 \mathrm{mGal}$ to $3.09 \mathrm{mGal}$, FAA anomaly has a range of $11.1 \mathrm{mGal}$ to $12.7 \mathrm{mGal}$ and gobs correction has range $978118.88 \mathrm{mGal}$ to $978118.50 \mathrm{mGal}$. Areas with high Bouguer anomalies have rock structures with high
\end{abstract}


density compared to other regions. The Bouguer anomaly value is getting to the north the lower, and increasingly south the higher.

Keywords: Bouguer anomaly, gravity, Kota Lama Semarang

\section{PENDAHULUAN}

Kota Semarang sebagai Ibu kota Jawa Tengah memiliki letak geografis terletak antara garis $6^{\circ} 50^{\prime}-7^{\circ} 10^{\prime}$ Lintang Selatan dan garis $109^{\circ} 35-110^{\circ} 50^{\prime}$ Bujur Timur, Ketinggian Kota Semarang terletak antara 0,75 sampai dengan 348,00 di atas garis pantai. Luas wilayah Kota Semarang tercatat $373,70 \mathrm{Km}^{2}$ (Murwanto, Sutarto, Rodhi, Nugroho, \& Budi, 2018).

Kota Lama termasuk daerah bagian utara kota semarang dengan kondisi geologi tanah berada di formasi aluvium. Selain itu di kota lama banyak sekali peninggalan bersejarah yang bisa kita jumpai, diantaranya adalah gereja tua peninggalan jaman Belanda dan Portugis yang bernama Gereja Blenduk yang merupakan mascot dari kawasan tersebut, berarsitektur tinggi dan megah (Puspitasari dan Khasana Ramli, 2018).

Perkembangan ini sayangnya dibarengi oleh munculnya masalah daya dukung wilayah yang tidak berimbang dan memicu permasalahan yang lebih kompleks dan bersifat sosio-ekonomis-kultural (Ikhsyan, Muryani, \& Rintayati, 2017). Contoh penurunan permukaan tanah. Penurunan tanah di kota Semarang berkisar $<0,6$ hingga $>3 \mathrm{~cm} /$ th. Penurunan yang cukup besar terjadi di bagian utara, yaitu sekitar pelabuhan Tanjung Emas, Stasiun Poncol hingga Stasiun Tawang (Wardhana, Harjono, \& Sudaryanto, 2014). Besar laju penurunan tanah kawasan Tawang, Pelabuhan, Kota Lama, Tanah Mas dari tahun 2013 sampai 2017 sebesar 2,07 17,04 cm/tahun(Prasetya, Yuwonodan Awaluddin, 2017) .

Sejumlah studi, khususnya geologi dan keteknikan, telah dilakukan untuk mengetahui penyebab penurunan muka tanah di Kota Lama Semarang. Hasil penelitian menunjukkan adanya korelasi antara pengambilan air tanah, endapan alluvial muda, dan pembebanan kota. Hasil pemodelan 2D menunjukkan bahwa penurunan tanah di Semarang umumnya lebih disebabkan oleh penurunan muka air tanah dan pembebanan permukaan (Sarah, Soebowo, \& Mulyono, 2013)

Penurunan muka tanah di Kota Semarang dikontrol oleh patahan yang ada atau sangat dipengaruhi oleh proses tektonik. Hal ini didasarkan pada kajian peta amblesan tanah, peta struktur geologi dan polamorfologi yang menunjukkan bahwa pola amblesan tanah berhubungan dengan pola struktur patahan (Sota, 2011). Kota Lama termasuk daerah bagian utara kota Semarang dengan kondisi geologi tanah berada di formasi alluvium (Supriyadi, Djuniadi, \& Hardyanto, 2015).

Pada penelitian ini menggunakan metode Anomali Gaya Berat Bouger (ABL) merupakan peta anomali gaya berat yang sudah dilakukan berbagai proses reduksi sehingga variasi nilai anomali percepatan gaya berat yang dihasilkan hanya dipengaruhi oleh variasi rapat massa dari bantuan di bawah permukaan. Nilai ABL ini adalah nilai total anomali yang ditimbulkan oleh pengaruh rapat massa batuan dari inti sampai permukaan bumi yang selanjutnya akan dipisahkan menjadi anomali regional dan residual. Interpretasi secara kualitatif dilakukan terhadap penyebaran daerah anomali residual di daerah penelitian yang dihubungkan dengan kondisi geologi dekat permukaan (Adhika, Karunianto, Junara. 2017). Metode tersebut sangat cocok digunakan di Kota Lama Semarang selain daerah tersebut jarang sekali digunakan penelitian disana, di kawasan Kota Lama Semarang memiliki info tersembunyi mengenai struktur bawah permukaan, dan kondisi geologi.

Oleh karena itu, penelitian ini bertujuan untuk melakukan analisis anomali Bouguer data gaya berat studi kasus di Kawasan Kota Lama Semarang untuk membantu mengidentifikasi struktur bawah permukaan tanah di Kawasan tersebut yang setiap tahunnya selalu terjadi banjir rob, genangan air dan penurunan permukaan tanah.

\section{METODE}

Pengukuran gaya berat dalam penelitian ini dilakukan pada 24 titik pengukuran yang tersebar di Kawasan Kota Lama selama 2 hari dengan cuaca yang sama menggunakan alat Gravitimeter Scientrex CG-5 Autograv dengan resolusi standar $1 \mu \mathrm{Gal}$ yang dilengkapi dengan antena GPS Garmin. 24 titik diambil karena untuk mengetahui dan menduga kondisi bawah permukaan daerah survey dapat dilakukan dengan metode gaya berat dengan cara mengamati variasi lateral dari densitas batuan dibawah permukaan (Nugraha, 2009). 
Pengolahan data dan koreksi terhadap nilai analisis Bouger menggunakan software Microsoft Excel untuk perhitungan matematis, sedangkan pengolahan data dalam membuat kontur anomaly Bouger menggunakan software Oasis Montaj 6.4.2.

Metode gaya berat merupakan salah satu metode geofisika yang memanfaatkan medan gravitasi Bumi akibat variasi rapat massa batuan di bawah permukaan tanah. Prinsip dasar dari metode ini adalah mengukur variasi nilai percepatan gravitasi yang ditimbulkan oleh adanya perbedaan rapat massa batuan yang berada di bawah permukaan Bumi(Yan et al., 2020).

Pengukuran gaya berat di lapangan banyak mengandung nilai-nilai yang bukan berasal dari refleksi bawah permukaan. Oleh karena itu sebelum data diolah dan diinterpretasikan lebih jauh diperlukan suatu proses reduksi yang berupa koreksi-koreksi terhadap nilai gaya berat hasil pengukuran lapangan. Koreksi-koreksi tersebut terdiri dari: (1) koreksi pasang surut, (2) koreksi apungan, (3) koreksi udara bebas, (4) koreksi Bouguer, (5) koreksi lintang, dan (6) koreksi medan(Araffa et al., 2015).

Data yang dihasilkan oleh alat gravitimeter dikoreksi awal menggunakan koreksi pasang surut dan koreksi apungan. Data yang telah dikoreksi kemudian diolah untuk mendapatkan nilai BA lengkap dengan cara melakukan koreksi lanjut berupa koreksi lintang, koreksi medan, serta koreksi ketinggian. Koreksi lintang digunakan untuk mengoreksi perbedaan gaya berat setiap lintang geografis karena adanya gaya sentrifugal dan bentuk ellipsoide. Umumnya koreksi lintang dilakukan untuk mendapatkan nilai gaya berat teoritis(Latifah, 2010). Koreksi medan tidak dilakukan dalam penelitian ini karena daerah Kota Lama Semarang datar. Koreksi ketinggian meliputi FAC dan BC. Secara matematis FAC dinyatakan oleh Persamaan 1.

$$
F A C=0,3086 . h
$$

Denganh ketinggian titik pengukuran di atas permukaan laut.

Nilai FAC digunakan untuk menentukan FAA yaitu selisih harga gaya berat pengamatan dengan harga gaya berat teoritis dan koreksi udarab ebasnya sesuai Persamaan 2.

$$
F A A=g_{o b s}-\left(g_{n}-F A C\right)
$$

Dengan gobs adalah nilai percepatan gravitasi observasi, $g_{n}$ adalah nilai percepatan gravitasi normal dihitung dengan Persamaan 3 (Yan et al., 2020).

$$
\begin{gathered}
g_{n}=978,0318\left(1+0,0053024 \sin ^{2} \emptyset-\right. \\
\left.0,0000058 \sin ^{2} 2 \varnothing\right) \text { gal }
\end{gathered}
$$

Koreksi Bouguer merupakan koreksi yang dilakukan untuk menghilangkan perbedaan ketinggian dengan tidak mengabaikan massa di bawahnya. Perbedaan ketinggian akan mempengaruhi besarnya percepatan gaya berat titik yang diamati diperoleh. Koreksi Bouguer (BC) diperoleh melalui Persamaan 4.

$$
B C=0.04191 . \rho h
$$

Dengan $\rho$ adalah background density yang besarnya $2.67 \mathrm{gr} / \mathrm{cc}$ dan $\mathrm{h}$ adalah ketinggian stasiun pengamatan.

Pada dasarnya anomali Bouguer adalah selisih antara nilai gaya berat pengukuran yang telah direduksi kebidang referensi ukuran dengan nilai gaya berat teoritis pada bidang referensi hitungan tertentu di suatu titik. Secara matematis anomali Bouguer dihitung dengan menggunakan Persamaan 5 (Telford, W.M., Sheriff, \& Keys, 2016).

$$
B A=g_{o b s}+F A C-B C+T C-g_{n}
$$

Anomali Bouguer yang diperoleh akan dijadikan sebagai dasar dalam pemodelan untuk interpretasi kuantitatif.

\section{HASIL DAN PEMBAHASAN}

Hasil pengolahan data gaya berat di Kawasan Kota Lama Semarang diperoleh peta konturanomali Bouguer lengkap seperti ditunjukkan pada Gambar 1. 


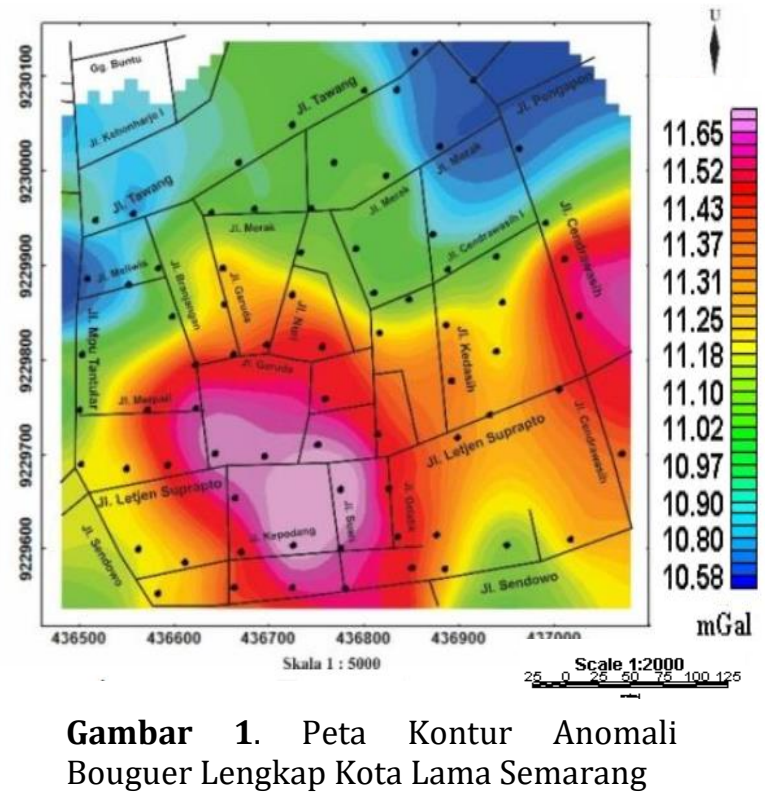

Gambar 1 menunjukkan peta kontur anomali Bouguer di Kota Lama Semarang denganskala1 : 2.000 hasil pengolahan data menggunakan software Oasis Montaj 6.4.2. Rentang anomali yang tergambar dalam peta adalah 10,58 mGals.d 11,65 mGal dengan arah Utara - Selatan. Terlihat bahwa nilai anomali Bouguer semakin tinggi dari arah Utara ke Selatan. Hal ini terlihat dari perbedaan warna konturnya dimana warna biru muda hingga biru merupakan nilai anomali Bouguer rendah, terkonsentrasi di sebelah utara sekitar Jalan Pengapon, sebagian Jalan Merak, sebagian Jalan Meliwis dan Jalan Tawang, sedangkan nilai anomali Bouguer tinggi terkonsentrasi di sebelah selatan yang ditunjukkan oleh warna merah hingga merah muda yang berada di sekitar Jalan Kepodang, Suari, sebagian Jalan Letjen Suprapto dan sebagian Jalan Cendrawasih.

Nilai anomali Bouguer yang tinggi mengindikasikan struktur batuan dengan densitas yang tinggi disbanding daerah sekitarnya, dan sebaliknya nilai anomali yang rendah memiliki struktur batuan dengan densitas yang rendah. Terlihat bahwa terdapat daerah yang memiliki kontur rapat di sekitar Jalan Kepodang dan Suari. Ketebalan lapisan batuan semakin besar kearah selatan. Dari gambaran tersebut bagian tengah dan utara, dilandasi oleh batuan dasar yang relative dalam.
Anomali Bouguer diperoleh dengan cara melakukan koreksi lanjut yaitu koreksi udara bebas (FAC) ditunjukkan Gambar 2.

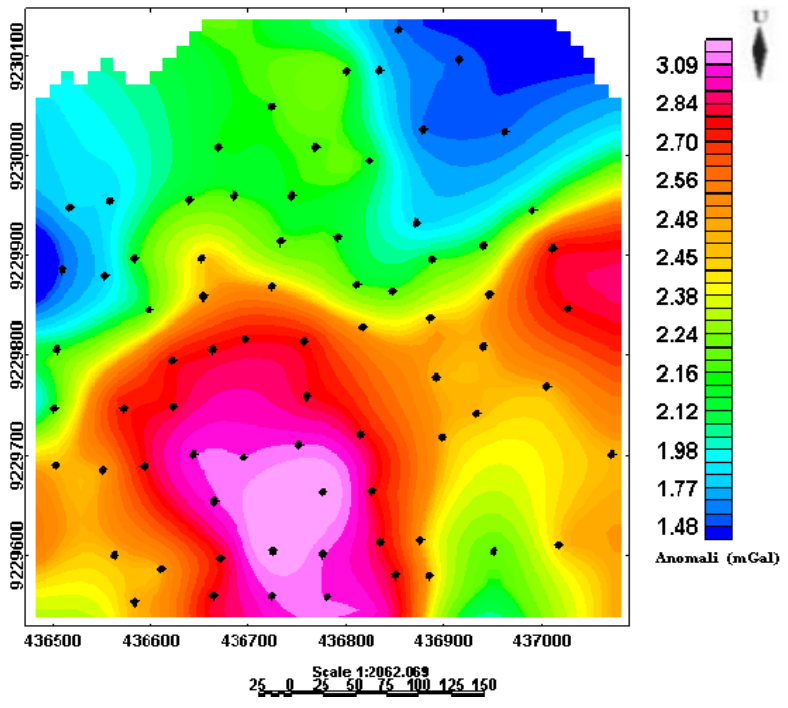

Gambar 2. Peta Kontur Koreksi FAC

Rentang anomali FAC yang tergambar dalam peta kontur Gambar 2. Adalah 1,48 mGal s.d 3,09 mGal. Anomali rendah ditunjukkan dengan warna biru yang terletak di utara, sedangkan anomali tinggi ditunjukkan warna merah muda yang terletak di selatan. Perubahan nilai anomali rendah ke tinggi yang sangat signifikan terjadi pada bagian timur. Perubahan terjadi karena perubahan kontras rapat massa batuan yang disebabkan terjadinya sedimentasi batuan.

Di bagian barat laut terjadi perubahan anomali rendah ke tinggi. Lokasi dengan nilai anomali rendah ditutupi oleh lapisan batuan sedimen tebal dengan kontras rapat massa kecil, selain itu fenomena tersebut patut diduga karena terlalu banyak dalam pengambilan air.

Data ini menunjukan bahwa daerah yang memiliki intensitas amblesnya tanah ditengah kota lama karena memiliki anomali tinggi dan disebabkan karena area padat penduduk dan tingginya bangunan yang berdiri. Padatnya penduduk tidak diimbangi dengan reboisasi yang menyebabkan rentan terjadi amblesnya tanah.

Nilai FAC digunakan untuk menentukan anomaly udara bebas (FAA). Hasil pengolahan data gaya berat dengan menggunakan FAA ditunjukkan Gambar 3. 


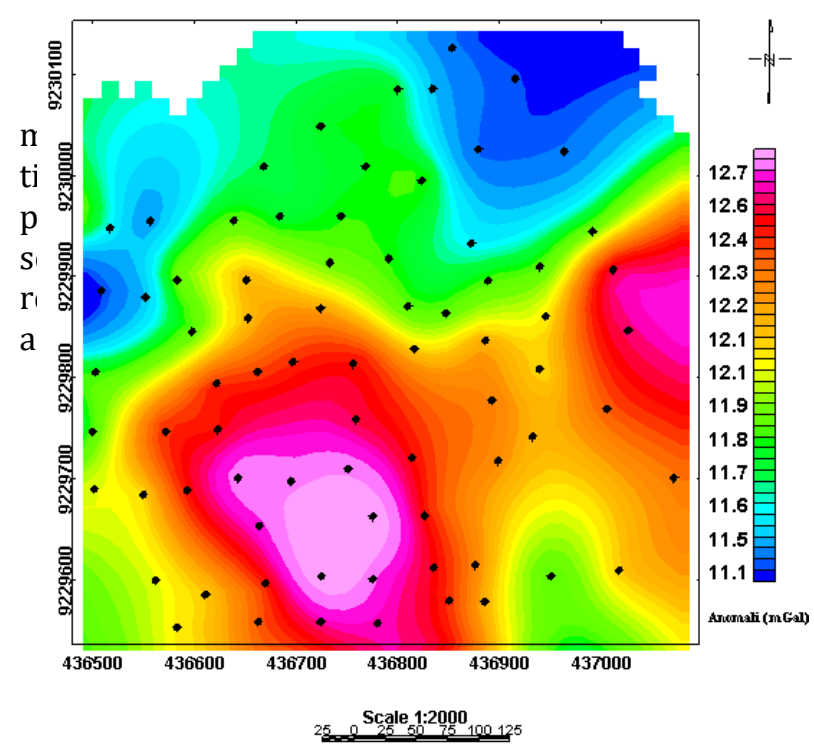

Gambar 3. Peta Kontur Anomali FAA

Nilai anomali regional yang rendah berada di bagian utara daerah penelitian di tunjukkan oleh warna biru dengan rentang 11,1 mGal s.d 11,6 mGal. Nilai anomaly tinggi ditunjukkan warna merah sampai merah muda yang memiliki rentang anomaly antara $12,4 \mathrm{mGal}$ s.d $12,7 \mathrm{mGal}$. Bagian tengah memiliki nilai anomaly sedang yang hamper merata kearah selatan dengan rentang dari 12,1 mGal s.d 12,2 mGal.

Anomali yang tinggi mengidentifikasi struktur batuan dengan densitas yang tinggi dibandingkan dengan daerah lainnya, dan yang memiliki nilai anomali rendah memiliki struktur batuan dengan densitas yang rendah. Peta kontur anomali FAA memperlihatkan ketebalan lapisan batuan semakin besar kearah selatan. Hal ini menunjukkan bahwa intensitas penurunan struktur bawah permukaan tanah semakin tinggi kearah selatan.

Koreksi yang kedua adalah nilai percepatan gravitasi observasi ( $g_{\text {obs}}$ ) yang sudah dikoreksi pasang surut dan koreksi drift ditunjukkan Gambar 4.

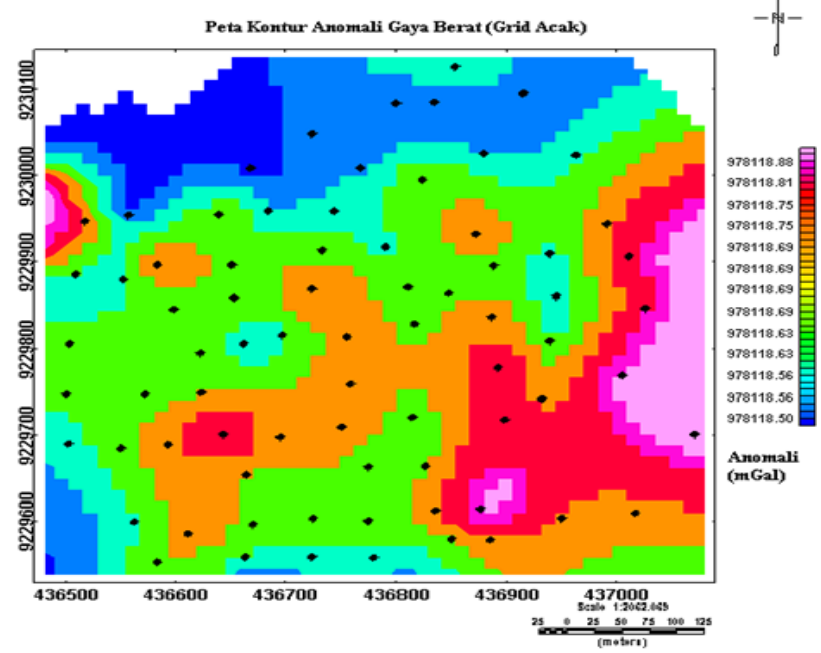

Gambar 4. Peta Kontur Koreksi gobs

Gambar 4 menampilkan peta kontur nilai gravitasi observasi (gobs). Kajian ini dilakukan untuk mengidentifikasi deformasi yaitu perubahan nilai rapat massa. Kontur yang diambil dengan menggunakan grid secara acak. Nilai gravitasi pengamatan yang tertinggi terdapat pada nilai $978118,88 \mathrm{mGal}$. Nilai Gobs rendah sebesar 978118,50 mGal. Peta kontur gravitasi pengamatan mengalami perubahan bentuk kontur dimana ditandai dengan kotak berwarna putih pada peta.

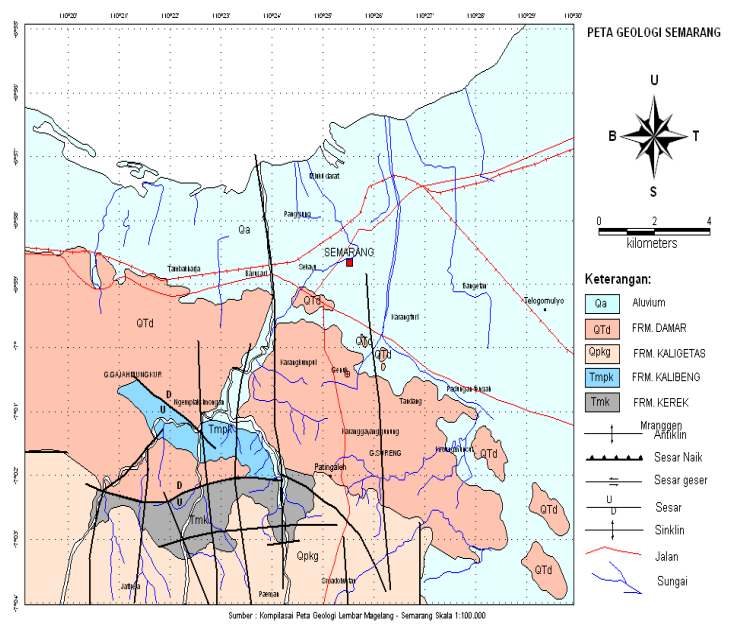

Gambar 5. Peta Geologi Semarang 
Di gambar 5 mmbuktikan bahwa bagian utara Kota Lama Semarang terdapat daerah pantai yang dipenuhi oleh pasir bukan batuan, sedangkan bagian selatan Kota Lama Semarang terdapat endapan batuan yang berumur muda, dan pengambilan air yang berlebihan mengakibatkan potensi penurunan struktur bawah tanah yang tinggi.

\section{KESIMPULAN}

Berdasarkan hasil analisis data anomaly Bouguer dapat disimpulkan bahwa di daerah bagian utara Kota Lama Semarang (sekitar Jalan Pengapon, sebagian Jalan Merak, sebagian Jalan Meliwis dan Jalan Tawang) memiliki gaya berat yang lebih kecil dibandingkan dengan di bagian selatan Kota Lama Semarang (sekitar Jalan Kepodang, Suari, sebagian Jalan LetjenSuprapto dan sebagian Jalan Cendrawasih).

\section{DAFTAR PUSTAKA}

Araffa, S. A. S., Helaly, A. S., Khozium, A., Lala, A. M. S., Soliman, S. A., \& Hassan, N. M. (2015). Delineating groundwater and subsurface structures by using 2D resistivity, gravity and 3D magnetic data interpretation around Cairo-Belbies Desert road, Egypt. NRIAG Journal of Astronomy and Geophysics, 4(1), 134-146 https://doi.org/10.1016/j.nrjag.2015.06.0 04

Ikhsyan, N., Muryani, C., \& Rintayati, P. (2017). Analisis Sebaran, Dampak dan Adaptasi Masyarakat Terhadap Banjir, Rob di Kecamatan Semarang timur dan Kecamatan Gayamsari Kota Semarang. Jurnal GeoEco, 3(2), 145-156.

Latifah, I. (2010). Penentuan Anomali Bouguer dan Densitas Rata- Rata Batuan Berdasrkan Data Gravitasi di Daerah Semarang.

Murwanto, Sutarto, H. and, Rodhi, S. and, Nugroho, A. and, \& Budi, A. R. (2018). Kajian Geologi Untuk Identifikasi Bencana di Wilayah Kota Semarang. Jurnal Kebencanaan Indonesia, 1(4), 240-258.
Prasetya, A. B., Yuwono, B. D., \& Awaluddin, M. (2017). Pemantauan Penurunan Muka Tanah Kota Lama Semarang Tahun 2016 menggunakan Perangkat Lunak Gamit 10.6. Jurnal Geodesi Undip, 6(2), 21-28.

Puspitasari, A. Y., \& Khasana Ramli, W. O. S. (2018). Masalah Dalam Pengelolaan Kota Lama Semarang Sebagai Nominasi Situs Warisan Dunia. Jurnal Planologi, 15(1), 96. https://doi.org/10.30659/jpsa.v15i1.2764

Sarah, D., Soebowo, E., \& Mulyono, A. (2013). Model Geologi Teknik Daerah Amblesan Tanah Kota. Prosiding Pemaparan Hasil Penelitian Puslit Geoteknologi, (December), 11-18.

Sota, I. (2011). Kajian Geologi Untuk Identifikasi Bencana di Wilayah Kota Semarang. Positron, 1(1), 25-30. https://doi.org/10.26418/positron.v1i1.15 65

Supriyadi, Djuniadi, \& Hardyanto, W. (2015). Pemodelan $2 \mathrm{~d}$ respon anomali gaya berat mikro antar waktu akibat amblesan dan dinamika muka air tanah. Jurnal Fisika Dan Aplikasinya, 16(1), 6-11.

Telford, W.M., L. P. G., Sheriff, R. E., \& Keys, D. A. (2016). Applied Geophysics. Cambridge: University Press,.

Wardhana, D. D., Harjono, H., \& Sudaryanto, S. (2014). Struktur Bawah Permukaan Kota Semarang Berdasarkan Data Gayaberat. Jurnal RISET Geologi Dan Pertambangan, 24(1), 53-64. https://doi.org/10.14203/risetgeotam201 4.v24.81

Yan, M., Zhang, Y., Bocobo, G. A., Su, Q., Zhu, K., Zhang, Q., \& Tan, J. (2020). A novel tissue separation method for determining upper trunk center of gravity in patients with thoracolumbar kyphosis using MIMICS. Clinical Biomechanics, 71(March 2019), 101-106. https://doi.org/10.1016/j.clinbiomech.201 9.11.002 